\title{
IMPROVING THE SERVICE WITH THE SERVQUAL METHOD
}

\author{
Katarzyna MIDOR \\ Silesian University of Technology \\ Marian KUČERA \\ Technical University in Zvolen
}

\begin{abstract}
:
At the time when economy is growing, there is strong competition in the market, and customers have increasingly higher expectations as regards quality of service and products. Under such conditions, organizations need to improve. One of the areas of improvement for an organization is to research the level of customer satisfaction. The article presents results of customer satisfaction surveys conducted by the Servqual method in a pharmaceutical service company. Use of this method allowed to improve the services provided by that pharmaceutical wholesaler, identify areas that need to be improved as soon as possible in order to improve the level of service provided.
\end{abstract}

Key words: improvement, service, quality, Servqual method, pharmaceutical wholesaler

\section{INTRODUCTION}

Progressive economic development, increased market competition and the globalization of market operations require from companies operating on the market to pursue effective actions to best meet their customers' needs in a competitive manner. Changes in international markets have forced companies to be highly competitive and a high level of service. In order to achieve profitable financial results, companies must improve quality-oriented management, in which it is important to develop an efficient business management system to maintain a high level of product or service quality, resulting in acquiring new customers and retention of old ones. The ISO 9001:2015 standard makes it clear that it is the responsibility of any organization that has a quality management system certification to measure customer satisfaction [8]. Organizations that aim to succeed in the market and achieve high profitability should treat customer satisfaction as their important goal. They also cannot forget to offer the highest quality products and services as these are the main determinants of achieving high customer satisfaction. For this reason, satisfaction should be measured in different dimensions (quality attributes) if it is to create the foundation for quality improvement. Satisfaction survey - esides providing information about processes that allow to implement improvements in services or products also plays an important role on another level. It informs the customer that the manufacturer or the service provider is aiming to get to know his/her opinion because it intends to improve the processes to meet his/her requirements and meet his/her expectations [7].

\section{QUANTITATIVE SERVICE QUALITY TEST METHOD - SERVQUAL}

Effective quality management in an organization means systematic performance in evaluating and testing the quali- ty of service performed. The results of analyses are the basis for improving the quality of services, as well as they result in continuous development of enterprises and the improvement of their quality activities.

Service quality testing is quite a difficult task, compared to testing the quality of products. The problem here is the nature of the service - its immateriality, instability, inseparability, individuality, and lack of ownership, and therefore the assessment of service quality is subjective. The assessment of the quality of service, depending on the person being tested, is varied. Every customer has different requirements, needs, preferences or evaluation criteria, hence there are divergences in the assessment [9].

The method that was chosen to solve the problem in this article is the Servqual (Service Quality) assessment method. It is a tool that organizations use to better understand the customers' needs and perceptions of their services. The method comes down to measuring the difference between the degree of satisfaction of expectations and the perception of services by the customer. More about this method can be found in $[1,2,3,6]$.

The Servqual method is designed to show the difference between the quality of service provided perceived by the customer and the quality provided by the organization. Such an assessment is made from the perspective of five dimensions of service quality. Research is based on the use of a specially created questionnaire. The questionnaire consists of two sections, each with 22 questions. Highlighted sections are [5]: expectation section - describes customer expectations for services and perception section - is an assessment of the quality of a company's services.

The assessment of these statements is measured using a 7-point Likert scale, where 7 means "I strongly agree" and 1 - "I strongly disagree". The Servqual claims for both sec- 
tions are categorized in five dimensions: tangibility, reliability, responsiveness, confidence and empathy.

The Servqual method has gained a lot of popularity over the past few years. Initially it was used only to examine the quality of banking services, but it can be used in libraries, universities, shopping malls, tourist services as well as smaller businesses such as beauty salons and hairdressing salons. This tool is simple and easy to implement, can be modified according to the needs of the organization and allows for accurate analysis. You can quickly locate problems and remove reasons of possible customer dissatisfaction and improve service quality [5].

\section{DESCRIPTION OF THE RESEARCH CARRIED OUT}

The improvement of customer satisfaction described in this article has been made in the pharmaceutical industry, on the example of a pharmaceutical wholesaler, which sells pharmaceuticals and medical products, as well as cosmetics, dietary supplements, hygiene products throughout Poland. The surveyed warehouse has many companies, also offers hotel and catering services [4]. The warehouse serves several hundred hospitals and several thousand pharmacies. In pursuit of continuous improvement of the offered services, the management of the company takes care of the highest level and wide range of services.

The X pharmaceutical wholesaler is well organized. Departments with direct contact with customers are: sales department, representative department, complaint department, transport department. Other departments that the customer sometimes needs to contact for various reasons are: warehouse, billing department.

There are two ways to place orders in the surveyed wholesale warehouse, namely by phone and by website. For the purposes of this article, ordering by phone will be discussed. Telephone orders mean that customers call the wholesaler themselves or the sales consultant calls the customer to accept an order. It depends on the preferences of each contractor. The employee is obliged to confirm the details of the pharmacy and then accept the order and send it to the warehouse. In the warehouse it is packed, delivered to the carrier and then a transport of goods for the customer is carried out. Everything is organized according to fixed border hours (hours to which the customer can place an order) and departure times (there are specified hours of departure of carriers on the specific routes).

Bearing in mind the continuous need to investigate customer satisfaction, a survey by Servqual has been proposed, which has not yet been used in research in the organization. Conducting to carry out the study, the first step was to specify the determinants that, according to the sales department director, sales manager and coordinators, have the greatest impact on customer satisfaction; then the most important determinants were selected using the brainstorming method. In the next step, the determinants were assigned to five areas:

1. Tangibility area:

- quality of the packed goods,

- wide range of the assortment,

- availability of assortment,

- availability and readability of information concerning operation of the wholesaler,

availability of promotional materials.

2. Reliability area:

- placing orders on schedule,

- deliveries on schedule,
- correctness of goods discharge,

- correctness of goods packing,

- ability to solve problems, resourcefulness.

3. Responsiveness area:

- staff willingness to help,

- speed of placing orders by phone,

- waiting time for connection with the sales department.

4. Confidence area:

- competence of employees,

- culture and professionalism of employees,

- trust in employees,

- correct approach to reported problems.

5. Empathy area:

- individual approach to each customer,

- taking into account customer needs, convenient working hours,

- convenient conditions of ordering,

- convenient trading terms,

- enough supplies during the day.

Based on the above list of statements, a Servqual questionnaire has been developed, which has been used to examine the satisfaction of customers, who was in this case pharmacy staff.

In practice, three Servqual questionnaires were sent to the e-mail addresses of the pharmacies, which concerned:

1. Questions developed for an ideal wholesaler, i.e. the one with which customers would like to work, i.e. "ideal",

2. The content relating to the studied $X$ wholesaler, these questions concern the evaluation of the services offered by the $X$ wholesaler,

3. Assessment of the importance of individual areas of the wholesaler's operation by the customer.

\section{RESULTS OF THE SURVEY}

The area for the study was Gdańsk. This is a wholesaler base that handles least pharmacies and no customer satisfaction analyses have been conducted before. The number of pharmacies in the adopted research area is 413 . The Servqual study was conducted within one week. Questionnaires were sent to 100 pharmacies by e-mail and one received responses from 45 pharmacies. Before each e-mail was sent, managers of the pharmacies were informed why the Servqual method was used and the rules for completing the Servqual questionnaire have been clarified so that there are no errors in answers. For research purposes, public pharmacies and pharmacy points have been selected. Answers to the questions were collected through Google forms.

The results of the Servqual study are presented by enumerating the so-called weighted and unweighted Servqual (SQ) score. The average unweighted Servqual score for all responses in the study was: -3.26 . For the individual areas of the company's operation, the unweighted Servqual score is shown in Figure 1.

The weighted average of Servqual values in the analysed study is -0.65 . For each area, the weighted average of Servqual is shown in Figure 2.

For all weighted and unweighted average results, Servqual values have been negative, which means that the quality of service expected by customers is different from that offered by the $X$ pharmaceutical wholesaler which is unsatisfactory. 
As a first for analysis, let's take into account the weighted value of Servqual. The results are as follows:

- tangibility area - total score -0.85 ,

- reliability area - total score -0.52 ,

- responsiveness area - total score -1.04 ,

- confidence area - total score -0.56,

- empathy area - total score -0.29.

One may find that most customers are dissatisfied with the responsiveness area. Questions in this group concerned:
- staff willingness to help,

- speed of placing orders by phone,

- waiting time for connection with the sales department.

Figure 3 shows the results from the responsiveness area.

The most unsatisfactory for customers is the waiting time for connection with a consultant, a total of -21 , and the speed of placing orders and staff willingness to help received the same total score -14 . The first to be improved should be this area of the wholesaler operation.

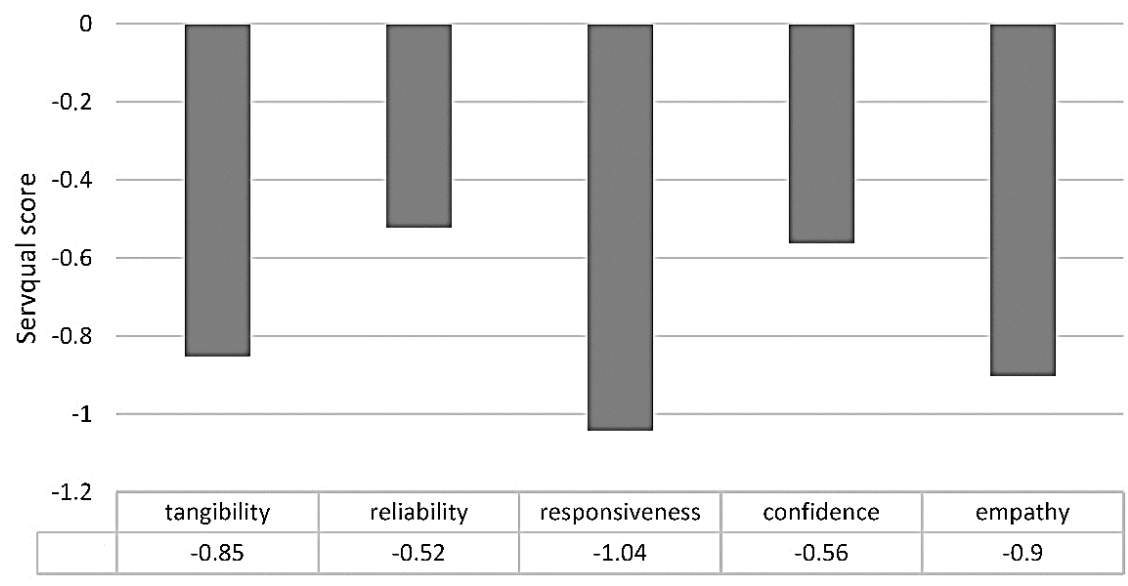

Fig. 1 Unweighted Servqual score for the group of pharmacies ordering by phone

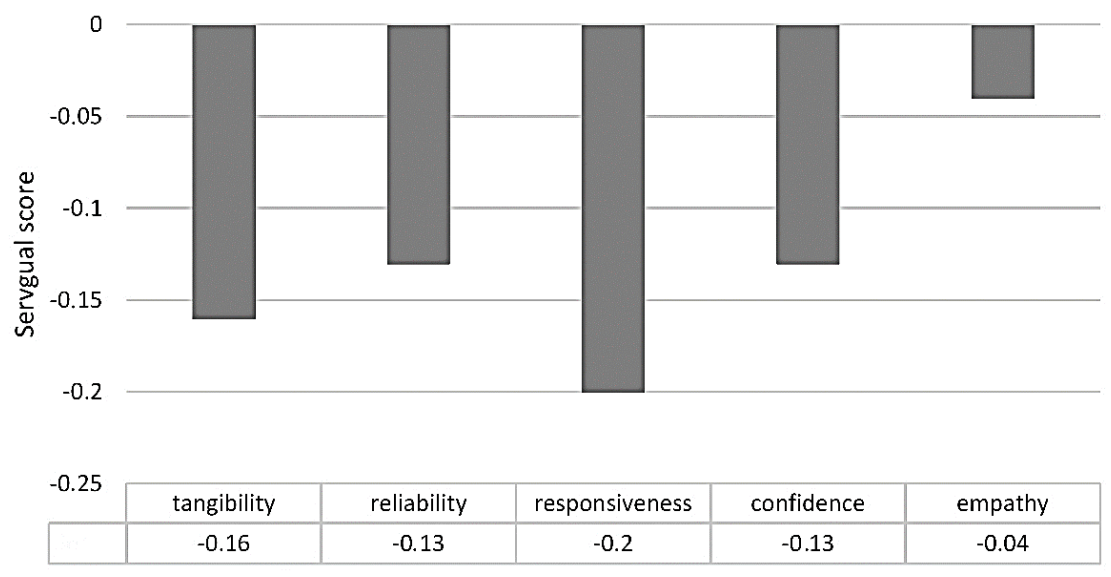

Fig. 2 Weighted Servqual score for each area for the group of pharmacies ordering by phone

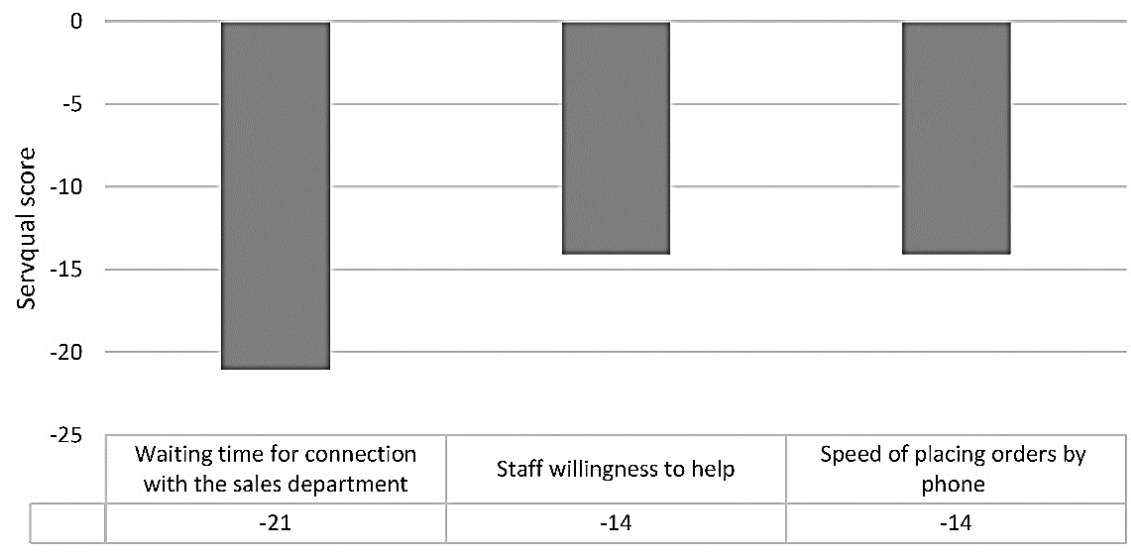

Fig. 3 Responses in the responsiveness area for the group of pharmacies ordering by phone 
The responsiveness area was worst evaluated by customers. This is an area that speaks of the desire to help the customer and provide him/her with fast service, as well as a quick response to the requirements. Customers who call the wholesalers every now and then, regarding patient orders, inquiries, problems, etc., expect reliable information and prompt action. In this case, the biggest problem is time that the customer devotes to waiting for connection with an employee. This factor needs immediate improvement. Then, the problem solving attitude of the staff - not evaluated as the consumer would like it to look. Skills of the sales team also proves to be a problem in the wholesaler.

Another area for which Servqual analysis has shown customer dissatisfaction is tangibility. In this area the questions concerned:

- quality of the packed goods,

- wide range of the assortment,

- availability of assortment,

- availability and readability of information concerning operation of the wholesaler,

- availability of promotional materials.

Figure 4 shows how the results for a particular issue are developed in the area in question.

Most consumers have reservations about the availability of the assortment, the sum of the answers is -28 , then the wide range of the assortment -24 , then the quality of the package, the fourth in this hierarchy is the availability of promotional materials -10 , then availability of information on operation of the wholesaler -8 .

The third area that requires change is the confidence area. Results for this area are presented in Figure 5.

From the above data it is clear that as soon as possible, improvement of the approach from the employees to the reported problems is required as soon as possible, the result being -17. Another aspect is the competence of employees, where the sum is -15 . The last is both the culture and professionalism of employees and the trust in employees where the score is -12 .

Taking into account the weighted value of Servqual, which is calculated from unweighted and average weights for each area, we obtained:

- tangibility area - weighted Servqual score -0.16,

- reliability area - weighted Servqual score -0.13,

- responsiveness area - weighted Servqual score -0.20,

- confidence area - weighted Servqual score -0.13,

- empathy area - weighted Servqual score -0.04.

According to the order of the greatest dissatisfaction from the areas that are to be improved first nothing is changed, the responsiveness area is the first to rank as based on calculation of the unweighted value of Servqual. Then the tangibility area, and a change is at the third place because it covers both the area of reliability and confidence. Therefore, the results for the reliability area will be discussed, as shown in Figure 6.

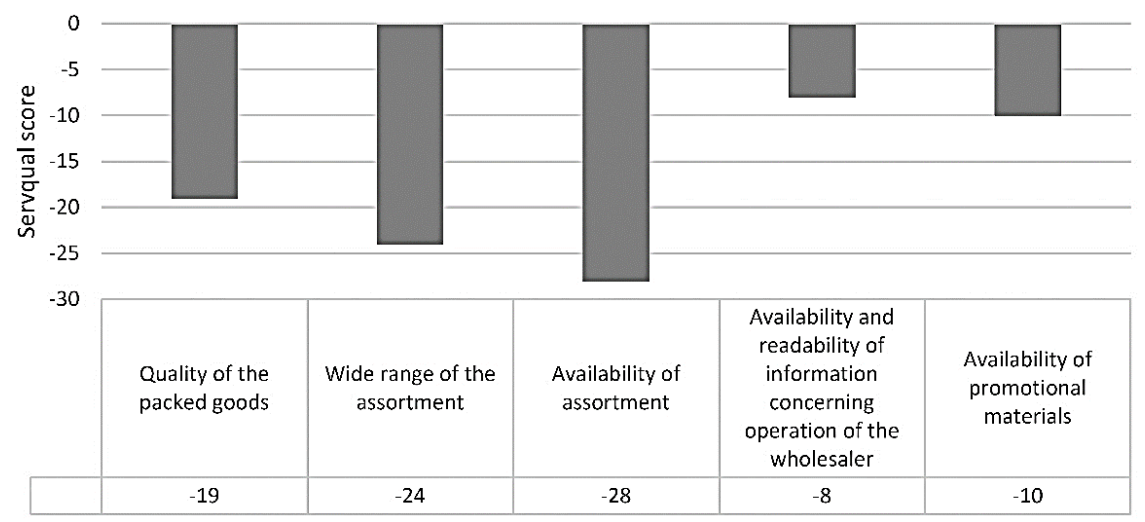

Fig. 4 Answers in the area of tangibility for the group of pharmacies ordering by phone

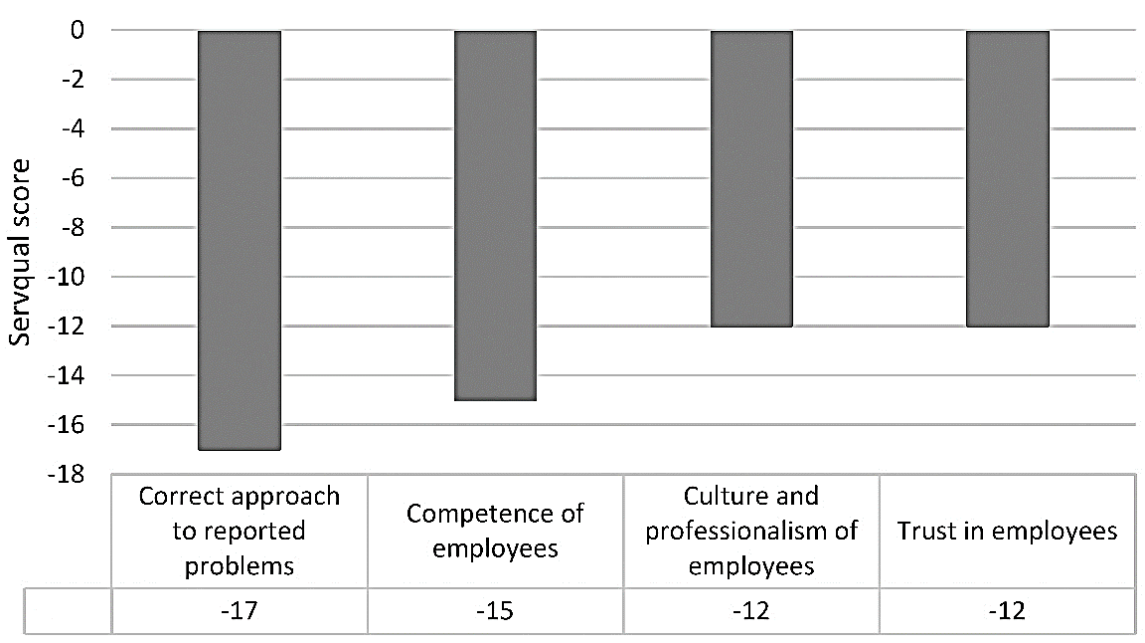

Fig. 5 Answers in the area of confidence for the group of pharmacies ordering by phone 


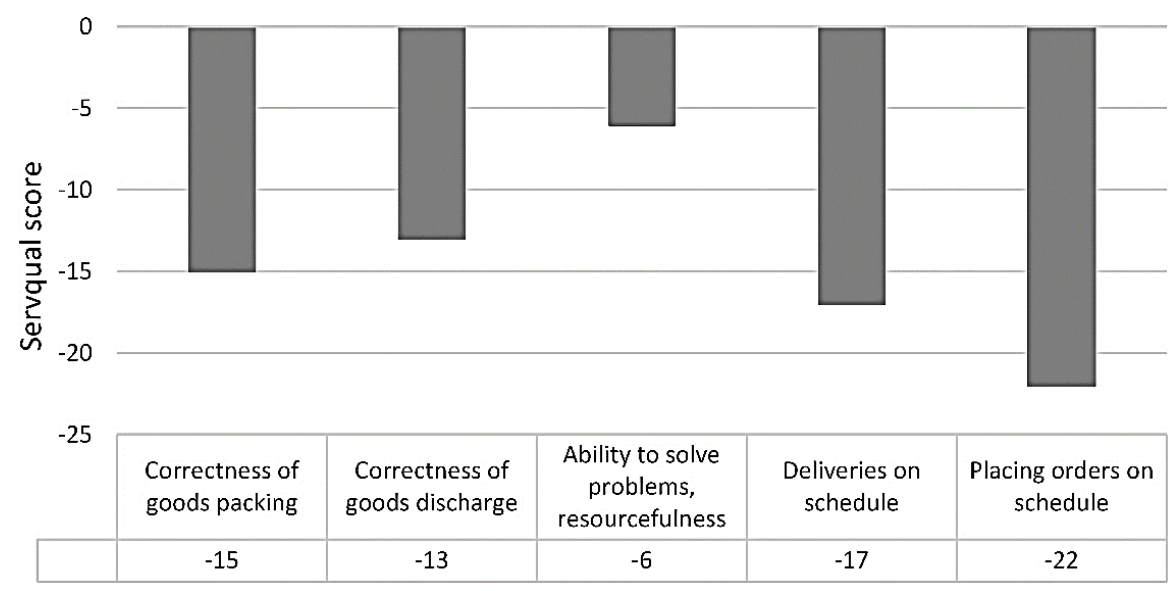

Fig. 6 Answers in the area of reliability for the group of pharmacies ordering by phone

The worst rated by customers is the correct packing: 22. Then correctness of goods discharge: -17 . Then placing orders on schedule: -15 , and deliveries on schedule: -13 , and last is the ability to solve problems by employees: -6 .

By analysing the results obtained from the part of the questionnaire on the weight, it is clear that for customers the most important areas in providing services for pharmacies ordering by telephone are:

- reliability area - average weight of 0.25 ,

- confidence area - average weight of 0.23 ,

- responsiveness area - average weight of 0.19 ,

- tangibility area - average weight of 0.18 ,

- empathy area - average weight of 0.15.

Accordingly, it can be said that the most important criterion for customers of the pharmaceutical wholesalers is reliability of the service. Accurate execution of an ordering process, including correct discharge of a product that the pharmacy expects, as well as correct packaging and delivery of the product to the customer on schedule, without delay.

The next thing that customers pay attention to is the speed of service. Consumers want to spend as little time as possible on ordering goods, and therefore skills of salespersons are important for them. Another issue is their flexibility. Ability to respond to new customer needs and ability to deal with emerging issues.

The third area of importance is the area of confidence. The main features that characterize this area are knowledge and competence of employees. Customers want to make sure that the service offered is being carried out by responsible people in a reliable manner.

Another area concerns the appearance of the outer packaging of the product, its availability, and the choice possibility. Another aspect that characterizes the discussed area is informing customers about changes in hours worked by the warehouse over the weekend, delays in delivering goods caused by external factors, or providing information on any promotions.

The last area where customers pay the least attention is empathy. The characteristics of this area include: customer care, individual approach to the customer, assurance of a range of ordering possibilities, a large quantity of daytime supplies and appropriate trading conditions.

\section{CONCLUSIONS}

The use of the Servqual Customer Satisfaction Survey helped improve the services provided by the pharmaceutical wholesaler, identify areas that need to be improved as quickly as possible in order to satisfy the customer as much as possible. Modern business management concepts consist of continuous improvement, so the wholesaler should not only be concerned about the proposed changes, but systematically conduct customer satisfaction surveys and implement further changes.

The results of the analysis show that the biggest problem in the wholesale market is human factor. Among the opportunities for improvement of human work, it is possible to distinguish the creation of a suitable organizational climate, whereby employees will have a sense of duty to strive to perform their duties properly, willingly, with optimism and with a sense of accomplishment at work. Factors that affect the working climate are:

- clarity - it is the employees' sense and understanding of what people are asking for and the knowledge of how these obligations relate to the goals and culture of the company as a whole,

- rewarding - it's about the good of employees, appropriate remuneration, so that everyone feels that his or her work and contribution to the company is appreciated,

- standards - this factor is characterized by commitment of management to the greatest involvement of employees in the performance of tasks. The quality of the tasks and the pursuit of continuous improvement are taken into consideration,

- flexibility - it is defined as a fast ability to change - in operation of wholesalers we mean employees' freedom of action, the ability of wholesalers to make rapid changes and openness to new ideas,

- responsibility - this factor determines the independence of employees, their autonomy, and the ability to decide on risk taking. It is a feeling that the range of delegated competencies is very broad,

- team engagement - the last factor that influences the working climate is a measure of employee's satisfaction of affiliation with the company. This satisfaction is in the desire to cooperate and to commit to work. 
The proposed change in the responsiveness area is primarily about improving the organizational climate by the management of the wholesaler to increase employees' activity, their willingness to work and satisfaction with their work and a sense of recognition. Another suggestion is the employment of additional employees, which would make the customers less nervous waiting for connection with a consultant.

This article was prepared within the statutory research titled "Methods and tools for improving products and services on the selected examples" work symbol 13/030/BK_17/0027 performed at Silesia University of Technology, Institute of Production Engineering.

\section{REFERENCES}

[1] U. Balon, A. Maziarczyk. „Satysfakcja klienta w systemie zarządzania jakością", in: Zarzqdzanie Jakościq. Doskonalenie organizacji. Kraków: UEK w Krakowie, 2010.

[2] Ch. Chakrapani. How to measure service quality and customer satisfaction. Chicago: American Marketing Association, 1998.
[3] R. Haffer. Satysfakcja konsumentów i jej pomiar. Warszawa: Wydawnictwo PWE, 2000.

[4] P. Kapica. „Badanie zadowolenia klienta zewnętrznego za pomocą metody Servgual w firmie usługowej". M.A. thesis, Wydział Organizacji i Zarządzania, Politechnika Śląska, Zabrze, 2017.

[5] E. Kreier, J. Łuczak. ISO 9000. Łatwy i skuteczny sposób uzyskania certyfikatu jakości. SERVQUAL - metoda oceny jakości usług. Poznań: FORUM, 2008.

[6] J. Kujawiński. „Niektóre metody oceny jakości usług,” in: Marketing 2001, vol. 2. Sopot: Katedra Turystyki i Usług Wydziału Zarządzania Uniwersytetu Gdańskiego, 1998.

[7] W. Mantura, A. Hamrol. Zarzqqdzanie jakościq. Teoria i praktyka. Warszawa: Wydawnictwo Naukowe PWN, 2006.

[8] PN-EN ISO 9001:2015 Systemy zarządzania Jakością. Wymagania.

[9] M. Stoma. Modele i metody pomiaru jakości usług. Lublin: Wydawnictwo Q\&R Polska, 2012.

\author{
dr inż. Katarzyna Midor \\ Silesian University of Technology \\ Faculty of Organization and Management \\ Institute of Production Engineering \\ ul. Roosevelta 26, 41-800 Zabrze, POLAND \\ e-mail: katarzyna.midor@polsl.pl \\ Doc. Ing. Marian Kučera, PhD \\ Technical University in Zvolen \\ Faculty of Environmental and Manufacturing Technology \\ Študentská 26, 96053 Zvolen, SLOVAK REPUBLIC \\ e-mail: kucera@tuzvo.sk
}

